\title{
Fizik Öğretmeni Adaylarının Temel Matematiksel İșlem Yeterliklerinin İncelenmesi
}

\section{Doç. Dr. Hasan Şahin Kızılcık ${ }^{1 *}$}

Geliş tarihi: 04.09.2019

Kabul tarihi: 17.10.2019

\section{Atıf bilgisi:}

IBAD Sosyal Bilimler Dergisi

Sayı: Özel Sayı $\quad$ Sayfa: 643-658

Yıl: 2019

This article was checked by iThenticate. Similarity Index $11 \%$.

${ }^{1}$ Gazi Üniversitesi, Türkiye, hskizilcik@gazi.edu.tr, ORCID ID 0000-0001-8622-0765

\footnotetext{
* Sorumlu Yazar
}

\section{ÖZ}

$\mathrm{Bu}$ çalışma, fizik öğretmeni adaylarının temel matematiksel işlem yapabilme yeterliklerini incelemeyi amaçlamaktadır. Bu amaçla, araştırmacı tarafından açık uçlu 20 maddeden oluşan bir ölçek geliştirilmiştir. Ölçek maddeleri; Temel İşlem Bilgisi, Köklü İfadelerde Temel İşlemler, Üslü İfadelerde Temel İşlemler, Logaritmik İfadelerde Temel İșlemler ve Temel Trigonometrik İșlemler olmak üzere temel matematiğin beş farklı konusunda dörder maddeden oluşturulmuştur. Maddeler kolay hesaplanabilir işlemlerden oluşmaktadır. Öğretmen adaylarından hesap makinesi kullanmadan ölçeğe yanıt vermeleri istenmiştir. Çalışma 98 öğretmen adayının katılımıyla gerçekleştirilmiştir. Ayrıca öğretmen adaylarından üçü ile görüşme yapılmıştır. Araştırma sonuçları, öğretmen adaylarının Temel İşlem Bilgisi bölümünde yeterli ancak diğer bölümlerde yetersiz olduklarını göstermiştir. Yapılan işlem hatalarının yanı sıra, işlem önceliğini belirleme, bazı temel işlem bilgilerinin yetersizliği ve özellikle üslü ifadelerde ve trigonometrik işlemlerde temel işlemlerde sorunlar belirlenmiștir. Ayrıca fizik öğretmeni adaylarının matematiksel işlem yeterliklerinin cinsiyetten bağımsız olduğu, ancak öğrenim yıll, üniversiteye giriş puanı ve güncel not ortalaması ile kısmen anlamlı olarak pozitif yönde ilişkili olduğu görülmüştür.

Anahtar Kelimeler: İşlem bilgisi, matematiksel beceri, fizik öğretmeni yetiştirme. 


\title{
Analysing of the Proficiency in Basic Mathematical Operations of Physics Teacher Candidates
}

\author{
Assoc. Prof. Dr. Hasan Şahin Kızılcık ${ }^{1 *}$
}

First received: 04.09.2019 Accepted: 17.10 .2019

\section{Citation:}

IBAD Journal of Social Sciences Issue: Special Issue Pages: 643-658 Year: 2019

This article was checked by iThenticate. Similarity Index $11 \%$.

${ }^{1}$ Gazi Universitiy, Turkey, hskizilcik@gazi.edu.tr,

ORCID ID 0000-0001-8622-0765

\footnotetext{
* Corresponding Author
}

\begin{abstract}
The aim of this study is to examine the proficiency in the basic mathematical operations of physics teacher candidates. For this purpose, a test consisting of 20 open-ended items was developed by the researcher. Scale items; Basic Operation Information, Basic Operations in Rooted Expressions, Basic Operations in Exponential Expressions, Basic Operations in Logarithmic Expressions and Basic Trigonometric Operations. Items consist of the numbers which are easily computable. Teacher candidates were asked to respond to the test without using a calculator. The study is applied to 98 teacher candidates. In addition, interviews are applied with three of teacher candidates. The results of the research showed that the pre-service teachers were sufficient in the Basic Operation Information section but were insufficient in other sections. In addition to the operation errors, the determination of the process priority, the inadequacy of some the basic process information and the problems in basic operations especially in exponential expressions and trigonometric operations were determined. In addition, it was seen that mathematical process proficiencies of physics teacher candidates were independent from gender but were significantly positive related to academic year university entrance point and current grade point average.
\end{abstract}

Keywords: Operation knowledge, numeracy, physics teacher training. 


\section{GíRIŞ}

Günümüzde, fen bilimleri alanında yetişmiş bireylerin varlığının hiç olmadığı kadar önemli olduğu bilinmektedir. Bilgi toplumunda, bireylerin fen bilimlerinde uzmanlaşmasa bile fen okuryazarlığına sahip olması gereklidir. Günümüzde fen okuryazarlığının yanı sıra, başka okuryazarlıklar da edindirmek eğitimde önemli görülmektedir (Tüzel, 2010). Bu okuryazarlıklar arasında ilişki olduğu yaygın bir görüştür. Bunlardan biri de matematik okuryazarlığıdır.

Bireylerin matematik okuryazarlığı yetisine sahip olabilmesi için çeşitli düzeylerde matematikle ilgili bazı temel yeterlik ve becerilerin edinilmesi gerekir (Bekdemir ve Duran, 2012). Bu temel yeterlik ve beceriler, Uluslararası Öğrenci Değerlendirme Programı (PISA)'nda içerik bilgisi, süreç (düşünme) ve güncellik (kullanıldığg durumlar) olmak üzere üç boyutta değerlendirmiştir (MEB, 2008). Ayrıca Uluslararası Yetişkin Eğitimi Sözlüğ̈̈’nde de "numeracy" kavramı, "temel matematik yeterlikleri”" biçiminde tanımlanmaktadır (Jarvis, 2005). Gündelik yaşamda "numeracy" kavramından çoğunlukla sayıları tanıma, kullanma ve temel dört işlemi yapabilme becerisi anlaşılmaktadır (Brown, 2002). Kısacası matematik okuryazarlığı gibi önemli görülen bir beceri için, temel matematik yeterlikler önkoşuldur. Kişinin öncelikle içerik bilgisine sahip olması gereklidir.

Umay (2007), matematiğin diğer bilim dalları içindeki yerinin göz ardı edilemeyeceğini belirtmekte ve matematiğin bir dil, düşünme biçimi olduğunu, matematikten yararlanmayan bir bilim dalı olmadığını söylemektedir. Matematiğin; fen bilimleri ve bilgisayar gibi alanların yanı sıra; dil, mimari, müzik, dans, tiyatro gibi sanat alanlarında ve sosyal bilimler ile eğitim alanları gibi birçok disiplinle ilişkisi olduğu bilinmektedir (Bodner, 2006). Günümüz toplumunda bireylerin edinmesi gerekli görülen becerilerden biri olan iletişim de matematiksel beceriler ile yakından ilgilidir (İpek ve Okumuş, 2012). Ayrıca matematik ile farklı disiplinler arasındaki ilişkilendirmeler yapılan çok sayıda çalışma yapılmıştır (Bodner, 2006; Flores, 1992; Monroe ve Mikovch, 1994). Schwalbach ve Dosemagen'e (2000) göre farklı disiplinler arasında ilişkilendirme (örneğin, matematik ve fen bilimleri arasında ilişkilendirme) üst düzey anlamsal kavrayışın yanında işlemsel bilgiyi de geliştirebilir. Eli (2009) problem çözme için matematiksel ilişkilendirmenin araç olduğunu belirtmektedir. Ancak, matematik bu denli önemli bir işleve sahip olmasına karşın öğrencilerin çoğu tarafından sevilmemekte, sıkıcı ve soyut bir ders olarak görülmektedir (Aksu, 1985).

Matematiksel bilgi, işlemlerin bilgisi (veya işlemsel bilgi) ve kavramsal bilgi olmak üzere iki aşamada incelenmektedir (Baykul, 2005). Kavramsal bilgi, matematik ile ilgili temel kavramları ve bu kavramlar arası ilişkiyi sözel olarak ifade ederken; işlemlerin bilgisi ise, matematikte kullanılan simgeler, kurallar ve matematik yaparken başvurulan işlemlerin bilgisi olarak tanımlanır (Baykul, 2005). İşlemsel bilgide, bir kavram ya da işlemin nedenini bilmeye gerek yoktur. Yalnızca işlemin nasıl kullanılacağını bilmek yeterlidir. Kavramsal bilgide ise kavrama öne çıkmaktadır (Baki, 1997). İşlemsel bilgi, problemleri çözmek için kullanılan simge, aritmetik işlem ve rutin kurallar bilgisidir (Hiebert ve Waerne, 1996). Buna göre, basit aritmetik işlemler, denklemler ve simgelerle gösterilen işlemler gibi sıradan kurallar işlem bilgisine birer örnektir (Bekdemir, Okur ve Gelen, 2010).

Matematiksel bir bilgiyi anlamanın koşulu, işlemsel ve kavramsal bilgilerin birbirleri ile bütünleşmesidir (Olkun ve Toluk, 2005). İşlemleri kurallar olarak öğrenen ve kavramlarla arasındaki bağı kuramayan bir bireyde ya ilgili kavramlar oluşmamış veya bu kavramlar oluşmuş olduğu halde işlemlerle kavramlar arasındaki bağ kurulmamış veya bunlardan birkaçı birden gerçekleşmemiş olabilir (Baykul, 2005). Kısaca, kavramsal bilginin kazanılması büyük ölçüde işlemsel bilginin kazanılmasını sağlamaktadır (Baki ve Kartal 2004; Hiebert ve Waerne, 1996; Perry, 1991; RittleJohnson ve Alibali, 1999). Dolayısıyla, işlem ve kavram bilgisini ayıran kesin bir çizgi yoktur (Baki, 1998).

Fen bilimlerinde ve fen bilimleri içinde yer alan fizikte başarının ilişkili olduğu önemli disiplinlerden biri olan matematik ile fen bilimlerinde başarının arasında bir ilişki olduğu alanyazında belirtilmiştir. Alanyazında, Fen Bilimleri ve Matematik derslerine yönelik başarılar arasında olumlu yönde yüksek bir korelasyonun olduğu ortaya konmuştur (Güleç ve Alkış, 2003; Wang, 2005). Matematiksel işlem bilgisi fen bilimlerinde sıklıkla kullanılmaktadır. Dolayısıyla, matematiksel işlem bilgisi ile fen bilimlerinde başarı arasında da doğal bir ilişki olduğu düşünülebilir. Bir bireyin, etkili bir fen eğitimi 
alabilmesi için matematiksel işlem becerilerini önceden edinmiş olması gereklidir. Fizik dersi, matematiğin dilinin en yoğun biçimde kullanıldığı derslerden biridir (Furner ve Kumar, 2007; Orton ve Roper, 2000). Bu nedenle Bütüner ve Uzun (2011), öğretmenlerin özellikle fizik öğretimi ve fen öğretiminde öğrencilerin matematik temelli sıkıntı yaşadıkları konusunda genel bir görüş belirttiklerini vurgulamışlardır.

Alanyazın incelendiğinde, matematiksel işlem bilgisi düzeyinde yapılan çalışmalar genellikle küçük yaştaki çocuklar üzerinde gerçekleştirilmiştir (Albayrak, İpek ve Işık, 2006; Çetinkaya ve Soybaş, 2018; Dursun ve Dede, 2004; Kaya ve Keşan, 2014). Türkiye'de doğrudan yetişkinlere matematik öğretimi konusunu veya yetişkinlerin matematik becerilerini ele alan bir çalışma bulunamamıştır. Yetişkin temel eğitimini ele alan çalışmalar da (Bülbül, Kavak, Gülbay vd., 1999; Güneş, 1990; Günlü, 2004; Nohl ve Sayılan, 2004; Yıldız, 2006, Yıldız, 2010) sinılı sayıdadır ve bu çalışmalar daha çok okuma-yazma becerisine yönelmiştir. Oysa gerek sosyal medyada gerekse günlük yaşamda temel işlemleri doğru biçimde yapmada güçlük çeken yetişkinlerin olduğuna tanıklık edilebilmektedir. $\mathrm{Bu}$ kişiler arasında üniversite eğitimi almış kişilerin bile yer alıyor olması ilginçtir. Matematik ögretiminde genel birtakım zorlukların yaşandığı bilinen bir gerçektir (Tutak, Gün ve Emül, 2010; Yenilmez, 2007). $\mathrm{Bu}$ nedenle yetişkinler arasında bile toplumun her kesiminde matematiksel yeterliklerin düzeyi incelenmelidir.

Öğretmenler de bu toplumun yetişkin bireyleri arasında yer almakta, hatta toplumun eğitiminde en önde görev almaları nedeniyle geleceğin yetişkinlerini yetiştirmeleri bakımından önemli konumdadırlar. $\mathrm{Bu}$ nedenle matematiksel işlem becerileri gibi temel becerilere, en başta öğretmenlerin sahip olması gerektiği açıktır. MEB tarafından yayınlanan öğretmen yeterlikleri içinde de bu duruma değinilmiştir (MEB, 2017). Alanyazın incelendiğinde, öğrencilerin matematiksel beceri düzeyleri ve çeşitli değişkenlerle ilişkilendirilmesine yönelik yapılmış araştırmalar olmasına karşın (Akyüz ve Pala, 2010; Özgen ve Bindak, 2011; Uysal ve Yenilmez, 2011) öğretmen adaylarının ve öğretmenlerin bu fen okuryazarlığı için altyapı teşkil eden matematiksel işlem bilgisi düzeylerinin tespitine yönelik çalışmalar sınırlı sayıdadır (Bütüner ve Uzun, 2011; Demir ve Akar Vural, 2017; Eli, 2009; Eli, MohrSchroeder ve Lee, 2011; Evitts, 2004; Güneş ve Gökçek, 2013; Korkmaz ve Gür, 2006; Tanışl1, 2013; Tekin ve Tekin, 2004; Uzun, Bütüner ve Yiğit, 2010). Bu çalışmaların önemli bir bölümü matematik ögretmenlerinin veya matematik öğretmeni adaylarının matematiksel yeterliklerine odaklanmaktadır. Fen bilgisi öğretmen adaylarının deneyimleri çerçevesinde değerlendirilen bir çalışmada, bu iki alan arasındaki ilişki vurgulanmıştır (Bütüner ve Uzun, 2011).

$\mathrm{Bu}$ araştırma, fizik öğretmeni adaylarının temel matematiksel işlem yeterliklerini incelemeyi amaçlamaktadır. Böylelikle matematik ile en çok iç içe olan fizik alanında öğretmen olmak üzere eğitim alan bireylerin toplumun kalanı gibi matematik ile ilgili temel düzeyde sorun yaşayıp yaşamadıkları görülebilecektir. Bu durum, öğretmen adaylarının öğretmenlik yaşamlarını ve gelecek kuşakları doğrudan etkileyeceğinden önemli görülmüştür.

\section{YÖNTEM}

Araştırma, tarama modelinde yapılmıştır. Araştırmanın verileri, araştırmacı tarafından geliştirilen açık uçlu bir ölçme aracı ile toplanmıştır. Öncelikle açık uçlu olarak toplanan nitel veriler ulamlara ayrılmış ve verilerin betimsel analiz tekniği değerlendirilerek betimleyici istatistikleri çıkarılmıştır. Kodlamalar sonucunda nicelleştirilen veriler, ayrıca istatistiksel çözümlemeler yardımıyla incelenmiştir.

İkinci aşamada, analizler sonucu en yüksek doğru yanıt veren, en düşük sayıda doğru yanıt veren ve ortancada bulunan öğretmen adayı olmak üzere üç öğretmen adayı ile görüşme yapılmıştır. Görüşmeler betimsel olarak incelenmiştir.

\section{Veri Toplama Aracı}

Çalışmanın verileri, araştırmacı tarafından geliştirilen açık uçlu 20 maddeden oluşan bir ölçek yardımı ile toplanmıştır. Ölçek, araştırmanın amacı doğrultusunda, farklı matematiksel işlem becerileri ölçecek biçimde açık uçlu olarak tasarlanmıştır. Ölçek maddeleri; Temel İşlem Bilgisi, Köklü İfadelerde Temel İşlemler, Üslü İfadelerde Temel İşlemler, Logaritmik İfadelerde Temel İşlemler ve Temel Trigonometrik İşlemler olmak üzere temel matematiğin beş farklı konusunu içerecek biçimde 
oluşturulmuştur. Her konu için dörder madde hazırlanmıştır. Amaç, öğretmen adayının ölçülmek istenen işlem yeterliğine sahip olup olmadığını belirlemek olduğundan, maddelerde yer alan açık uçlu sorular, hesaplaması kolay sayılardan seçilmiştir.

Ölçek açık uçlu olarak oluşturulduğundan geçerlilik ve güvenilirlik için açık uçlu ölçeklerde kapsam geçerliliği ve tutarlılık önem kazanmaktadır (Lincoln ve Guba, 1985). Ölçeğin kapsam geçerliliği uzman görüşü alınarak belirlenmiştir. Fizik eğitimi alanında doktoralı üç araştırmacıdan görüş alınmıştır ve kapsam geçerliliği sağlanmıştır. Uzmanların görüş birliği \%85 düzeyindedir. Tutarlılığ1 sağlamak için, öğrencilerin benzer maddelere verdiği yanıtlar karşılaştırılmıştır.

Görüşme yapılan öğretmen adayları ile yanlış yanıt verdikleri ve boş bıraktıkları maddeler ile ilgili görüşülmüştür. Görüşme, yüz yüze yapılmış ve ortalamada $8,3 \mathrm{dk}$. sürmüştür.

\section{Çalışma Öbeği}

Araştırmanın çalışma öbeğini Ankara'da bulunan bir üniversitenin fizik öğretmenliği ana bilim dalında öğrenim gören öğrenciler oluşturmaktadır. Söz konusu öğrenciler, eğitim fakültesinde öğrenim gördükleri için aynı zamanda öğretmen adayı olarak nitelendirilebilir. Çalışma, öğreniminin farklı yıllarında olmakla birlikte toplamda 98 öğretmen adayı ile gerçekleştirilmiştir. Çalışma öbeğini oluşturan öğretmen adaylarının cinsiyete ve öğrenim yıllarına göre dağılımı Tablo 1'de verilmiştir.

Tablo 1: Çalışma öbeğinin dağılımı

\begin{tabular}{lcccc}
\hline Yll / Cinsiyet & Kadın & Erkek & Belirsiz & Toplam \\
\hline 1. Yil & 14 & 6 & 0 & 20 \\
2. Y1 & 11 & 3 & 1 & 15 \\
3. Y1 & 8 & 7 & 1 & 16 \\
4. Y11 & 18 & 0 & 0 & 18 \\
5. Y1 & 9 & 5 & 0 & 14 \\
5+ Yil & 11 & 3 & 0 & 14 \\
Belirsiz & 0 & 1 & 0 & 1 \\
\hline Toplam & $\mathbf{7 1}$ & $\mathbf{2 5}$ & $\mathbf{2}$ & $\mathbf{9 8}$ \\
\hline
\end{tabular}

Tablo 1'de görüldüğü gibi, çalışmaya katılan öğretmen adaylarının 71'i kadın, 25'i erkektir ve 2'si ise cinsiyet belirtmemiştir. Çalışmaya katılan öğretmen adayları eğitimlerinin farklı yıllarındadırlar. Ayrıca çalışmanın gerçekleştirildiği 2018 yılında ana bilim dalının normal öğretim süresi 4 yıl olmasına karşın, öğrenimlerinin 5. yılında ve daha üstünde bulunan çok sayıda (N: 28) öğretmen adayı bulunmaktadır.

\section{Verilerin Analiz Yöntemi}

Veriler, açık uçlu bir ölçekten edinildiği için nitel özelliktedir ve yanıtın doğru olup olmadığı araştırmacı tarafından belirlenmiştir. Bunun için, maddelere verilen yanıtlar araştırmacı tarafindan önceden belirlenen doğru yanıtlar ile karşılaştırılmıştır. Ölçek sorularına verilen yanıtlardan doğru olarak kabul edilenlere örnekler Tablo 2'de verilmiştir. 
Tablo 2: Doğru kabul edilen yanitlara örnekler

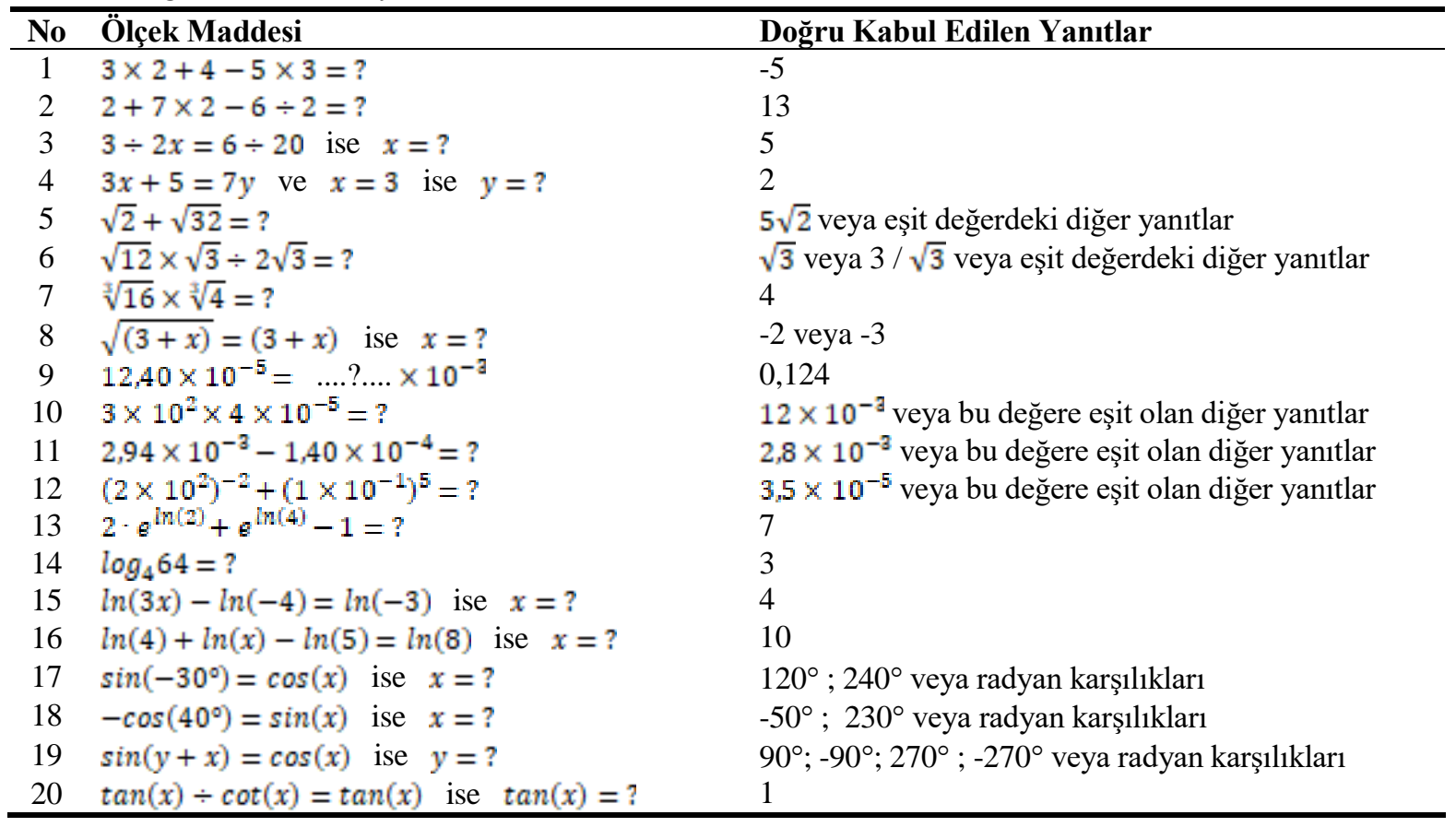

Tablo 2'de yer alan yanıtlar doğru olarak kabul edilmiş olmasına karşın, bu yanıtların dışında verilen ve bu yanıtlara matematiksel olarak eşdeğer olan yanıtlar da doğru olarak alınmıştır. Birden fazla doğru yanıtı bulunan maddelerde, doğru yanıtlardan yalnızca birini veren öğretmen adayı, doğru yanıt vermiş kabul edilmiştir. Tüm olası doğru yanıtları vermesi beklenmemiştir.

Yanıtlar değerlendirilirken, doğru yanıtlar "D", yanlış yanıtlar ise "Y" olarak kodlanmıştır. Boş bırakılan yanıtlara ise "B" kodu verilmiştir. Daha sonra her bir ölçek maddesi ayrı ayrı ve içinde bulunduğu ulamdaki diğer maddelerle birlikte değerlendirilerek istatistikleri çıkarılmıştır.

Daha sonra, her doğru yanıt için 1 , her yanlış yanıt için ise 0 puan verilerek her bir öğretmen adayı için 20 üzerinden bir puan belirlenmiştir. Söz konusu puan, cinsiyet ve öğrenim yılı gibi değişkenlere göre karşılaştırma yapmak amacıyla birtakım istatistikler çözümlemeler için kullanılmıştır.

Yapılan görüşmeler, betimsel analiz yöntemi ile değerlendirilmiş ve sonuçların yorumlanmasında kullanılmıştır.

\section{BULGULAR VE YORUM}

İlk olarak ölçeğin beș ulamını oluşturan maddeler ulam içinde değerlendirilmiş ve böylelikle her ulam için ortalama doğru ve yanlış yanıtlar ile boş bırakılan yanıtların ortalamaları ve ortalama yüzdeleri belirlenmiştir. Söz konusu veriler Tablo 3'te görülmektedir.

Tablo 3: Ulamlara göre ölçeğin yanıtlarının dağılımı

\begin{tabular}{lccccccc}
\hline Ulamlar & $\begin{array}{c}\text { Madde } \\
\text { Sayısı }\end{array}$ & $\mathbf{D}$ & $\mathbf{D} \%$ & $\mathbf{Y}$ & Y \% & B & B \% \\
\hline Temel İşlem Bilgisi & 4 & 3,78 & 94,39 & 0,19 & 4,85 & 0,03 & 0,77 \\
Köklü İfadelerde Temel İşlemler & 4 & 2,38 & 59,44 & 1,19 & 29,85 & 0,43 & 10,71 \\
Üslü İfadelerde Temel İşlemler & 4 & 1,60 & 40,05 & 2,03 & 50,77 & 0,37 & 9,18 \\
Logaritmik İfadelerde Temel İşlemler & 4 & 1,45 & 36,22 & 1,20 & 30,10 & 1,35 & 33,67 \\
Temel Trigonometrik İşlemler & 4 & 0,86 & 21,43 & 1,84 & 45,92 & 1,31 & 32,65 \\
\hline Toplam & $\mathbf{2 0}$ & $\mathbf{1 0 , 2 9}$ & $\mathbf{5 1 , 4 3}$ & $\mathbf{6 , 4 6}$ & $\mathbf{3 2 , 3 0}$ & $\mathbf{3 , 4 8}$ & $\mathbf{1 7 , 4 0}$ \\
\hline
\end{tabular}

Tablo 3'e göre, toplamda 20 madde içinde doğru yanıtların ortalama değeri 10,29 düzeyindedir. Bu da \%51,43 oranında olmaktadır. Bu durum, öğretmen adaylarının \%50'ye yakının ölçeği oluşturan 20 maddeye doğru yanıt verirken, diğer \%50’ye yakın kısmının ise doğru yanıt veremediği anlamına 
gelmektedir. Bunların \%32,30'u yanlış yanıt vermiş, \%17,40’1 ise boş bırakmıştır. Bunlar, ölçeğin düzeyi düşünüldüğünde oldukça yüksek oranlardır.

Tablo 3 incelendiğinde, öğretmen adaylarının Temel İşlem Bilgisi ulamında yer alan maddelere \%94,39 oranında doğru yanıt (D) verdiği görülmektedir. Oysa Köklü İfadelerde temel İşlemler ulamında bu oran \%59,44'e düşmüş, diğer üç ulamda ise bu değer \%50'nin de altına inmiştir. Temel Trigonometrik İşlemler ulamında \%21,43'e dek düşerek en düşük düzeye ulaşmıştır.

Yanlış yanıtlara (Y) bakıldığında ise, yanlış yanıtlar, doğru yanıtlara ilişkin istatistiklere uygun olarak Temel İşlem Bilgisi ulamında \%4,85 düzeyindedir. Ancak farklı olarak bu kez en çok yanlış yanıt verilen ulam, \%50,77 ile Üslü İfadelerde Temel İşlemler ulamı olmuştur. İkinci sırada ise \%45,92 ile Temel Trigonometrik İşlemler ulamı gelmektedir.

Boş bırakılan yanıtlarda (B), \%33,67 ve \%32,65 oranları ile sırasıyla Logaritmik İfadelerde Temel İşlemler ve Temel Trigonometrik İşlemler ulamları en yüksek değerdedir. Yine \%0,77 oranı ile Temel İşlem Bilgisi ulamındaki maddeler, en az boş bırakılan maddeler olmuştur.

Tablo 3’teki verilere göre, öğretmen adaylarının Temel İşlem Bilgisi ulamı dışındaki diğer tüm ulamlarla ilgili yeterlikleri tartışılabilir. Çünkü bu dört ulam, bir biçimiyle oldukça yüksek oranda boş bırakılmış ya da yanlış yanıt verilmiştir. Bu durumun ayrıntılarını belirlemek için ulamları oluşturan maddeler ayrı ayrı incelenmelidir. Bu nedenle her bir ulam ayrı ayrı ele alınmış ve tüm maddeler incelenmiştir.

\section{Temel İşlem Bilgisi Ulamı}

Ölçekteki ilk dört madde (1-4 numaralı), Temel İşlem Bilgisi ulamında yer almaktadır. Bu ulamdaki maddelerden ilk ikisi dört işlemde işlem önceliği, diğer ikisi ise birinci derecen bir bilinmeyenli denklem çözme becerisi ile ilişkilidir. Tablo 4'te Temel İşlem Bilgisi ulamında yer alan dört ölçek maddesine verilen yanıtların dağılımı görülmektedir.

Tablo 4: Temel İşlem Bilgisi ulamına verilen yanıtların dağglımı

\begin{tabular}{clcccccc}
\hline No & Maddeler & $\mathbf{N}_{\mathbf{D}}$ & $\mathbf{N}_{\mathbf{D}} \%$ & $\mathbf{N}_{\mathbf{Y}}$ & $\mathbf{N}_{\mathbf{Y}} \%$ & $\mathbf{N}_{\mathbf{B}}$ & $\mathbf{N}_{\mathbf{B}} \%$ \\
\hline 1 & $3 \times 2+4-5 \times 3=?$ & 95 & 96,94 & 3 & 3,06 & 0 & 0,00 \\
2 & $2+7 \times 2-6 \div 2=?$ & 91 & 92,86 & 5 & 5,10 & 2 & 2,04 \\
3 & $3 \div 2 x=6 \div 20$ ise $x=?$ & 89 & 90,82 & 8 & 8,16 & 1 & 1,02 \\
4 & $3 x+5=7 y$ ve $x=3$ ise $y=?$ & 95 & 96,94 & 3 & 3,06 & 0 & 0,00 \\
\hline & Ortalama & $\mathbf{9 2 , 5 0}$ & $\mathbf{9 4 , 3 9}$ & $\mathbf{4 , 7 5}$ & $\mathbf{4 , 8 5}$ & $\mathbf{0 , 7 5}$ & $\mathbf{0 , 7 7}$ \\
\hline
\end{tabular}

Tablo 4'te görüldüğü gibi, Temel İşlem Bilgisi ulamında yer alan dört maddenin tamamına verilen yanıtlar içinde doğru yanıtların oranı \%90'ın üzerindedir. En çok yanlış yanıt oranı \%8,16 ile 3 numaralı maddede görülmüştür. Diğer yandan yanıtsız bırakılan soru neredeyse yoktur. Özellikle 1 ve 4 numaralı maddelerde bu oran sifirdır.

$\mathrm{Bu}$ bağlamda, öğretmen adaylarının Temel İşlem Bilgisi ile ilgili maddelerde genel bir sorun yaşamadıkları söylenebilir. Az sayıdaki yanlış yanıt incelendiğinde, çoğunlukla işlem önceliğini belirlemede hata veya işlem hatası göze çarpmaktadır.

\section{Köklü İfadelerde Temel İşlemler Ulamı}

Ölçekteki ikinci dört madde (5-8 numaral1), Köklü İfadelerde Temel İşlemler ulamında yer almaktadır. Bu ulamda yer alan maddelerden ilk ikisi (5. madde) köklü ifadelerde dört işlemi en temel düzeyde ele almaktadır. Bu ulamdaki 3. maddede (Madde 7) ise farklı olarak kökün derecesi değiştirilmiştir. Ulamın son maddesinde (8. madde), köklü ifadelerden oluşan bir bilinmeyenli birinci dereceden basit bir denklem kurulmuştur. Tablo 5'te söz konusu maddelere verilen yanıtların dağılımı görülmektedir. 
Tablo 5: Köklü İfadelerde Temel İşlemler ulamına verilen yanıtların dağılımı

\begin{tabular}{clcccccc}
\hline No & Maddeler & $\mathbf{N}_{\mathbf{D}}$ & $\mathbf{N}_{\mathbf{D}} \%$ & $\mathbf{N}_{\mathbf{Y}}$ & $\mathbf{N}_{\mathbf{Y}} \%$ & $\mathbf{N}_{\mathbf{B}}$ & $\mathbf{N}_{\mathbf{B}} \%$ \\
\hline 5 & $\sqrt{2}+\sqrt{32}=?$ & 78 & 79,59 & 15 & 15,31 & 5 & 5,10 \\
6 & $\sqrt{12} \times \sqrt{3} \div 2 \sqrt{3}=?$ & 51 & 52,04 & 44 & 44,90 & 3 & 3,06 \\
7 & $\sqrt[3]{16} \times \sqrt[3]{4}=?$ & 57 & 58,16 & 27 & 27,55 & 14 & 14,29 \\
8 & $\sqrt{(3+x)}=(3+x)$ ise $x=?$ & 47 & 47,96 & 31 & 31,63 & 20 & 20,41 \\
\hline & Ortalama & $\mathbf{5 8 , 2 5}$ & $\mathbf{5 9 , 4 4}$ & $\mathbf{2 9 , 2 5}$ & $\mathbf{2 9 , 8 5}$ & $\mathbf{1 0 , 5 0}$ & $\mathbf{1 0 , 7 1}$ \\
\hline
\end{tabular}

Tablo 5'teki veriler, bu ulamdaki maddelere verilen yanıtların ortalama olarak $\% 58,25$ 'ine doğru yanıt verildiğini göstermektedir. En çok doğru yanıt \%79,59 oranı ile 5 numaralı maddede görülmektedir. Doğru yanıtların en az görüldüğü madde ise, \%47,96 oranı ile 8 numaralı madde olmuştur. Yine 8 numaralı madde, \%20,41 ile ulamda en çok boş bırakılan maddedir. Diğer yandan, en çok yanlış yanıt verilen madde ise \%44,90 gibi yüksek bir oranla 6 numaralı madde olmuştur.

Öğretmen adaylarının Köklü İfadelerde Temel İşlemler ulamında yanıt vermekte zorlanarak en çok boş bıraktığı durumun köklü ifadelerle kurulan birinci dereceden bir bilinmeyenli denklem olması ilginçtir. Denklemi nasıl çözeceğine karar veremeyen öğretmen adaylarının oranının bu denli yüksek olması, öğretmen adaylarının Temel İşlem Bilgisi ulamında yüksek olduğu görülen denklem çözme becerini, köklü ifadelere uyarlamakta güçlük çektiği biçiminde yorumlanabilir. Bu maddeye doğru yanıt verenlerin \%50'nin altında kalması da bu bağlamda değerlendirilebilir.

Diğer yandan, en çok yanlış yanıt verilen maddenin köklü ifadelerde çarpma ve bölme işlemleri ile ilgili olan 6 numaralı maddede olması diğer şaşırtıcı bir sonuçtur. Oysa, her ne kadar 7 numaralı maddeyi boş bırakma oranı azımsanmayacak ölçüde yüksek olsa da kök derecesi değişmiş olmasına karşın çarpma işlemi daha düşük oranda yanlış yanıtlanmıştır. Buradan çarpma ve bölme işlemlerini bir arada yaparken bir sorun yaşandığı düşünülebilir. Ayrıca öğretmen adayları, 7 numaralı maddede kökün derecesi değiş̧tiği için yapamayacaklarına ilişkin bir önyargıya kapılarak boş bırakmayı yeğlemiş, ancak 6 numaralı maddede özgüvenli biçimde yanıt vermeye yönelmiş olabilirler.

\section{Üslü İfadelerde Temel İșlemler Ulamı}

Ölçekteki üçüncü dört madde (9-12 numaral1), Üslü İfadelerde Temel İşlemler ulamında yer almaktadır. Bu ulamda, fizikte en çok kullanılan 10'un kuvveti biçiminde ifade edilen sayılar ile işlemlere ilişskin sorular ele alınmıştır. Bu yüzden ulamın ilk maddesi olan 9 numaralı maddede, ögretmen adaylarından herhangi bir üslü ifadeyi istenen başka bir dereceye dönüştürmeleri beklenmiştir. Ardından 10 ve 11 numaralı maddelerde üslü ifadeler arasında dört işlem yapmaları beklenmiştir. Son olarak 12 numaralı maddede düzey artırılmış ve üslü ifadelerin kuvvetinin alınması ile elde edilen yeni sayılar arasındaki işlemleri yapmaları beklenmiştir. Tablo 6'da söz konusu maddelere verilen yanıtların dağılımı görülmektedir.

Tablo 6: Üslü İfadelerde Temel İşlemler ulamına verilen yanıtların dağılımı

\begin{tabular}{clcccccc}
\hline No & Maddeler & $\mathbf{N}_{\mathbf{D}}$ & $\mathbf{N}_{\mathbf{D}} \%$ & $\mathbf{N}_{\mathbf{Y}}$ & $\mathbf{N}_{\mathbf{Y}} \%$ & $\mathbf{N}_{\mathbf{B}}$ & $\mathbf{N}_{\mathbf{B}} \%$ \\
\hline 9 & $12,40 \times 10^{-5}=\ldots ? \times 10^{-\mathbf{a}}$ & 38 & 38,78 & 55 & 56,12 & 5 & 5,10 \\
10 & $3 \times 10^{2} \times 4 \times 10^{-5}=?$ & 83 & 84,69 & 14 & 14,29 & 1 & 1,02 \\
11 & $2,94 \times 10^{-1}-1,40 \times 10^{-4}=?$ & 28 & 28,57 & 62 & 63,27 & 8 & 8,16 \\
12 & $\left(2 \times 10^{2}\right)^{-2}+\left(1 \times 10^{-1}\right)^{5}=?$ & 8 & 8,16 & 68 & 69,39 & 22 & 22,45 \\
\hline & Ortalama & $\mathbf{3 9 , 2 5}$ & $\mathbf{4 0 , 0 5}$ & $\mathbf{4 9 , 7 5}$ & $\mathbf{5 0 , 7 7}$ & $\mathbf{9 , 0 0}$ & $\mathbf{9 , 1 8}$ \\
\hline
\end{tabular}

Tablo 6'ya bakıldığında ortalamada yanıtların \%50,77'sinin yanlış, \%40,05'inin doğru olduğu görülmektedir. Yanlış yanıtların oranının doğru yanıtlardan çok olduğu görülmüştür. Yalnızca \%9,18'i boş bırakılmıştır. En çok doğru yanıt \%84,69 ile 10 numaralı maddeye verilirken, en az doğru yanıt $\% 8,16$ gibi oldukça düşük oranda 12 numaralı maddeye verilmiştir. Diğer yandan, yanlış yanıtların oranına bakıldığında 10 numaralı madde dışındaki 9, 11 ve 12 numaralı maddelerdeki oranın \%50'nin üzerinde olması ilginçtir. Diğer yandan 12 numaralı soru \%22,45 gibi yüksek bir oranda yanıtsız bırakılmıştır.

Öğretmen adaylarının, maddelerde verilen işlemler içinde üslü ifadelerde çarpma işlemi dışındaki işlemlerde oldukça yetersiz olduğu söylenebilir. Üs değiştirme, üslü ifadelerde toplama ve çıkarma, 
özellikle de üslü ifadelerin kuvvetini alma konusunda sorun yaşamaktadırlar. Yanlış yanıtlar incelendiğinde, en çok toplama, çıkarma ve genel anlamda üst değiştirme hatalarının olduğu görülmüştür.

\section{Logaritmik İfadelerde Temel İşlemler Ulamı}

Ölçekteki dördüncü dört madde (13-16 numaral1), Logaritmik İfadelerde Temel İşlemler ulamında yer almaktadır. Bu ulamdaki maddeler en temel logaritmik özellikleri yansıtacak biçimde seçilmiştir. Bu amaçla, ulamın ilk sorusu olan 13 numaralı soruda eksponansiyel ifade ile doğal logaritma arasındaki ilişkiye dayalı bir işlem verilmiştir. Daha sonra 14 numaralı soruda öğretmen adaylarından farklı bir tabanda basit bir logaritma alma işlemi yapmaları beklenmiştir. Ulamdaki son iki madde (15 ve 16 numaralı), logaritmik ifadeler arası dört işlem ile ilgilidir ve bu işlemlerin özelliklerinden yararlanarak birinci dereceden bir bilinmeyenli denklem çözme becerisini sorgulamaktadır. Tablo 7'de söz konusu maddelere verilen yanıtların dağılımı görülmektedir.

Tablo 7: Logaritmik İfadelerde Temel İşlemler ulamına verilen yanıtların dağılımı

\begin{tabular}{clcccccc}
\hline No & Maddeler & $\mathbf{N}_{\mathbf{D}}$ & $\mathbf{N}_{\mathbf{D}} \%$ & $\mathbf{N}_{\mathbf{Y}}$ & $\mathbf{N}_{\mathbf{Y}} \%$ & $\mathbf{N}_{\mathbf{B}}$ & $\mathbf{N}_{\mathbf{B}} \%$ \\
\hline 13 & $2 \cdot e^{[\ln [2]}+e^{[\ln [4]}-1=?$ & 35 & 35,71 & 19 & 19,39 & 44 & 44,90 \\
14 & $\log _{4} 64=?$ & 56 & 57,14 & 33 & 33,67 & 9 & 9,18 \\
15 & $\ln (3 x)-\ln (-4)=\ln (-3)$ ise $x=?$ & 26 & 26,53 & 33 & 33,67 & 39 & 39,80 \\
16 & $\ln (4)+\ln (x)-\ln (5)=\ln (8)$ ise $x=?$ & 25 & 25,51 & 33 & 33,67 & 40 & 40,82 \\
\hline & Ortalama & $\mathbf{3 5 , 5 0}$ & $\mathbf{3 6 , 2 2}$ & $\mathbf{2 9 , 5 0}$ & $\mathbf{3 0 , 1 0}$ & $\mathbf{3 3 , 0 0}$ & $\mathbf{3 3 , 6 7}$ \\
\hline
\end{tabular}

Tablo 7'deki veriler, ortalamada doğru yanıtların oranının bu ulam için \%35,50 oranında olduğunu, yanlış yanıtların \%29,50 oranında olduğunu ve boş bırakılan maddelerin ise \%33,67 oranında olduğunu göstermektedir. Maddeler içinde 14 numaralı madde dışında hiçbir maddeye \%50'nin üzerinde doğru yanıt verilmemiştir. Ayrıca diğer üç sorunun tümünde boş bırakılma oranı hem doğru hem de yanlış yanıtlardan daha çoktur.

Öğretmen adaylarının basit logaritma alma konusunda \%50'den yüksek oranda doğru yanıtı bulması olumludur. Ancak işlemin basitliği göz önüne alındığında yeterli olduğu söylenemez. Ayrıca logaritmik ifadelerin özellikleri konusunda oldukça yetersiz oldukları söylenebilir. Bu durum düşündürücüdür.

\section{Temel Trigonometrik İşlemler Ulamı}

Ölçekteki son dört madde (17-20 numaralı), Temel Trigonometrik İşlemler ulamında yer almaktadır. Her ne kadar bu ulam Temel Trigonometrik İşlemler olarak adlandırılmış olsa da yalnızca ulamdaki son madde (20 numaralı) trigonometrik ifadelerle basit bir işlemi içermektedir. Diğer üç madde ise trigonometrik ifadelerin birbirine dönüştürülmesi ile ilgilidir. Aralarındaki temel fark, açının veya ifadenin pozitif veya negatif oluşu ile hangi trigonometrik bölgede yer aldığıdır. Tablo 8'de söz konusu maddelere verilen yanıtların dağılımı görülmektedir.

Tablo 8: Temel Trigonometrik İşlemler ulamına verilen yanıtların dağılımı

\begin{tabular}{lllcccccc}
\hline No & Maddeler & & $\mathbf{N}_{\mathbf{D}}$ & $\mathbf{N}_{\mathbf{D}} \mathbf{\%}$ & $\mathbf{N}_{\mathbf{Y}}$ & $\mathbf{N}_{\mathbf{Y}} \mathbf{\%}$ & $\mathbf{N}_{\mathbf{B}}$ & $\mathbf{N}_{\mathbf{B}} \mathbf{\%}$ \\
\hline 17 & $\sin \left(-30^{\circ}\right)=\cos (x)$ ise $x=?$ & 20 & 20,41 & 65 & 66,33 & 13 & 13,27 \\
18 & $-\cos \left(40^{\circ}\right)=\sin (x)$ ise $x=?$ & 14 & 14,29 & 49 & 50,00 & 35 & 35,71 \\
19 & $\sin (y+x)=\cos (x)$ ise $y=?$ & 17 & 17,35 & 39 & 39,80 & 42 & 42,86 \\
20 & $\tan (x) \div \cot (x)=\tan (x)$ ise $\tan (x)=$ & 33 & 33,67 & 27 & 27,55 & 38 & 38,78 \\
\hline & Ortalama & $\mathbf{2 1 , 0 0}$ & $\mathbf{2 1 , 4 3}$ & $\mathbf{4 5 , 0 0}$ & $\mathbf{4 5 , 9 2}$ & $\mathbf{3 2 , 0 0}$ & $\mathbf{3 2 , 6 5}$ \\
\hline
\end{tabular}

Tablo 8'deki veriler, yanlış yanıtların ortalamada \%45,92 oranı ile en yüksek oranda olduğunu göstermektedir. Ardından \%32,65 ile boş bırakılan maddeler gelmektedir. Doğru yanıt oranı ise $\% 21,43$ 'te kalmıştır. Ulamdaki ilk iki soruda (17 ve 18 numaralı) yanlış yanıt oranı \%50 ve üstündedir. Tüm sorularda ise doğru yanıt oranı \%50'nin çok altında kalmıştır. Ayrıca 19 ve 20 numaralı maddelerde boş bırakma oranı hem doğru hem de yanlış yanıtların oranlarının üzerindedir.

Genel olarak öğretmen adaylarının trigonometrik ifadeler konusunda kendilerine verilen maddelere doğru yanıt vermekte oldukça yetersiz olduğu söylenebilir. Maddeleri gerek yanıtsız bırakma oranları gerekse yanlış yanıt verme oranları bu durumu göstermektedir. Yanlış yanıtlar incelendiğinde, en çok 
yapılan hatanın açının bulunduğu bölgenin dikkate alınmamış olması veya değerin pozitif veya negatif olmasının önemsenmemesi olduğu görülmüştür.

\section{Verilerin Demografik Özelliklere Göre Karșılaștırılması}

Öğretmen adaylarının ölçeğe verdikleri yanıtlar nicel verilere dönüştürülerek çalışma öbeğinin demografik özelliklerine göre karşılaştırılmıştır. Öğretmen adaylarından, cinsiyet ve öğrenim yılı bilgilerinin yanı sıra, üniversiteye giriş sınavından aldıkları puanlar ve güncel not ortalamaları bilgileri de istenmiştir. Söz konusu veriler Tablo 9'da sunulmuştur.

Tablo 9: Grupların ulamlara göre ortalama puanları

\begin{tabular}{|c|c|c|c|c|c|c|}
\hline Yil & Cinsiyet & $\begin{array}{l}\text { Temel İşlem } \\
\text { Bilgisi Puanı }\end{array}$ & $\begin{array}{c}\text { Köklü } \\
\text { İfadelerde } \\
\text { Temel İşlemler } \\
\text { Puanı } \\
\end{array}$ & $\begin{array}{c}\text { Üslü İfadelerde } \\
\text { Temel İşlemler } \\
\text { Puanı }\end{array}$ & $\begin{array}{c}\text { Logaritmik } \\
\text { İfadelerde } \\
\text { Temel İşlemler } \\
\text { Puanı } \\
\end{array}$ & $\begin{array}{c}\text { Temel } \\
\text { Trigonometrik } \\
\text { İşlemler Puanı }\end{array}$ \\
\hline \multirow{3}{*}{ 1. Y1l } & $\mathrm{K}$ & 4,00 & 2,43 & 0,79 & 1,57 & 0,71 \\
\hline & $\mathrm{E}$ & 4,00 & 2,00 & 1,67 & 1,50 & 0,67 \\
\hline & Toplam & 4,00 & 2,30 & $\mathbf{1 , 0 5}$ & 1,55 & $\mathbf{0 , 7 0}$ \\
\hline \multirow{3}{*}{ 2. Y1l } & $\mathrm{K}$ & 3,82 & 2,09 & 1,27 & 1,82 & 1,09 \\
\hline & $\mathrm{E}$ & 4,00 & 3,33 & 1,33 & 1,33 & 0,33 \\
\hline & Toplam & 3,80 & 2,47 & 1,33 & 1,67 & $\mathbf{0 , 8 7}$ \\
\hline \multirow{3}{*}{ 3. Y1l } & $\mathrm{K}$ & 3,75 & 2,00 & 1,63 & 1,38 & 1,00 \\
\hline & $\mathrm{E}$ & 3,57 & 1,71 & 2,14 & 1,14 & 0,57 \\
\hline & Toplam & 3,69 & $\mathbf{1 , 8 8}$ & 1,94 & 1,25 & 0,75 \\
\hline \multirow{3}{*}{ 4. Y1l } & $\mathrm{K}$ & 3,67 & 2,72 & 1,72 & 1,17 & 1,00 \\
\hline & $\mathrm{E}$ & - & - & - & - & - \\
\hline & Toplam & 3,67 & 2,72 & 1,72 & 1,17 & $\mathbf{1 , 0 0}$ \\
\hline \multirow{3}{*}{ 5. Y1l } & $\mathrm{K}$ & 4,00 & 2,11 & 1,33 & 1,00 & 0,56 \\
\hline & $\mathrm{E}$ & 3,60 & 2,00 & 1,60 & 1,20 & 0,40 \\
\hline & Toplam & 3,86 & 2,07 & 1,43 & 1,07 & $\mathbf{0 , 5 0}$ \\
\hline \multirow{3}{*}{$5+Y_{1} l$} & $\mathrm{~K}$ & 3,55 & 2,36 & 2,09 & 1,82 & 1,27 \\
\hline & $\mathrm{E}$ & 3,75 & 4,00 & 2,75 & 2,50 & 1,50 \\
\hline & Toplam & 3,60 & 2,80 & 2,27 & 2,00 & 1,33 \\
\hline
\end{tabular}

Tablo 9'daki verilere bakıldığında, 1. yılındaki tüm öğretmen adaylarının Temel İşlem Bilgisi ulamında tam puan aldıkları görülmektedir. Diğer yandan Temel Trigonometrik İşlemler ulamında ise en düşük puanı yine 1. yılındaki öğretmen adayları almıştır. Genel olarak, üst düzey ulamlarda eğitiminin ilk yıllarındaki öğretmen adaylarının daha düşük, alt düzey ulamlarda ise daha yüksek puan aldıkları söylenebilir. Cinsiyet açısından da ulamlarda farklılıklar görülmektedir. $\mathrm{Bu}$ farkların istatistiksel olarak anlamlı olup olmadığına bakılmıştır.

Öncelikle cinsiyet değişkenine göre her bir ulam puanı ve genel puan verileri karşılaştırılmıştır. Bu amaçla istatistik yazılımları aracılığı ile MANOVA (Çoklu Varyans Analizi) kullanılmıştır. Böylelikle deneysel hata en aza indirgenmeye çalışılmıştır. Cinsiyet değişkenine göre yapılan MANOVA sonuçları (Wilks' Lambda: 0,279; p: 0,079) anlamlı düzeyde bulunamamıştır ( $p>0,05)$. Buna göre, cinsiyete göre gerek ulam puanları gerekse genel puan açısından cinsiyet grupları arasında anlamlı düzeyde bir fark yoktur denebilir. Bu nedenle ayırıcı analizlere gerek duyulmamıştır.

İkinci olarak öğretmen adaylarının öğrenim yılı değişkeni ve üniversiteye giriş sınavından aldıkları puanlar ile güncel not ortalamaları değişkenleri ele alınmıştır. Bu üç değişken için de Pearson Momentler Çarpımı Korelasyon katsayıları hesaplanmıştır ve her bir ulamın puanı ve genel puan ile söz konusu değişkenlerin anlamlı ilgileri olup olamadığı belirlenmiştir. Söz konusu veriler Tablo 10 'da verilmiştir. 
Tablo 10: Korelasyon analizi verileri

\begin{tabular}{lcccccc}
\hline & \multicolumn{2}{c}{ Öğrenim Yılı } & \multicolumn{2}{c}{ Giriş Puanı } & \multicolumn{2}{c}{ Not Ortalaması } \\
\cline { 2 - 7 } & $\mathbf{r}$ & $\mathbf{p}$ & $\mathbf{r}$ & $\mathbf{p}$ & $\mathbf{r}$ & $\mathbf{p}$ \\
\hline Temel İşlem Bilgisi Puanı & $-0,219$ & 0,031 & 0,084 & 0,718 & $-0,099$ & 0,444 \\
Köklü İfadelerde Temel İşlemler Puanı & 0,144 & 0,159 & 0,061 & 0,793 & 0,198 & 0,122 \\
Üslü İfadelerde Temel İşlemler Puanı & 0,321 & 0,001 & 0,581 & 0,006 & $-0,048$ & 0,712 \\
Logaritmik İfadelerde Temel İşlemler Puanı & 0,060 & 0,561 & 0,493 & 0,023 & 0,294 & 0,020 \\
Temel Trigonometrik İşlemler Puanı & 0,162 & 0,114 & 0,005 & 0,982 & 0,287 & 0,024 \\
\hline Genel Puan & $\mathbf{0 , 1 7 2}$ & $\mathbf{0 , 0 9 2}$ & $\mathbf{0 , 4 5 3}$ & $\mathbf{0 , 0 3 9}$ & $\mathbf{0 , 2 5 7}$ & $\mathbf{0 , 0 4 4}$ \\
\hline
\end{tabular}

Tablo 10'da sunulan verilere göre, genel puanlar açısından üniversiteye giriş sınavı puanı ve güncel not ortalaması ile ölçek puanları arasında anlamlı bir ilişki olduğu söylenebilir $(\mathrm{p} \leq 0,05)$. Bu ilişki pozitif yöndedir ve üniversiteye giriş sınavı puanı ve güncel not ortalaması arttıkça öğretmen adaylarının ölçekten aldıkları puanlar da anlamlı düzeyde artmaktadır.

Ulamlar temelinde incelendiğinde ise, Temel İşlem Bilgisi ulamından alınan puanlar ile öğrenim yılı arasında ters ve anlamlı bir ilişki olduğu görülmektedir. Bu durumda, öğrencilerin öğrenim yılı arttıkça ölçekten ilgili ulamda aldıkları puan anlamlı düzeyde düşmektedir. Bu durum ilginçtir. Çünkü üniversite eğitimlerinde daha ileri yıllarda olan öğretmen adaylarının Temel İşlem Bilgisi konusunda zayıfladığı biçiminde algılanabilir. Ancak bu ulamda doğru yanıtların genel olarak \%90'ın üzerinde olması dikkat çekicidir.

Üslü İfadelerde Temel İşlemler ulamından alınan puanlar ile öğrenim yılı ve üniversiteye giriş sınavı puanı arasında pozitif yönde anlamlı ilişki bulunmuştur. Pozitif anlamlı ilişki, Logaritmik İfadelerde Temel İşlemler ulamından alınan puan ile üniversiteye giriş sınavı puanı ve güncel not ortalaması arasında da bulunmuştur. Temel Trigonometrik İşlemler ulamından alınan puanlar ile güncel not ortalaması arasında da benzer bir pozitif anlamlı ilişki belirlenmiştir.

Belirlenen pozitif anlamlı ilişkiler incelendiğinde, öğrenim y1lı arttıkça üslü ifadelerde temel İşlemler ulamı dışında hiçbir ulamda anlamlı bir ilişki olmaması, üniversitedeki öğrenim yaşamlarının öğretmen adaylarının temel matematiksel işlem becerilerine önemli ölçüde etkisinin olmadığını göstermektedir denebilir. Diğer yandan üniversite yaşamlarında aldıkları derslerde üslü ifadelerde sıklıkla işlem yapılıyor olması, bu yeterliklerinin gelişimine etki etmiş olabilir.

Üniversiteye giriş sınavı puanı ve güncel not ortalaması değişkenlerinin hem genel hem de iki farklı ulam ile anlamlı ilişkiye sahip olması ilginçtir. Öğretmen adayları üniversiteye farklı yıllarda girmiştir. Üniversiteye giriş sınavı puanı ile öğrenim yılı arasında (r: 0,318; p: 0,161) ve güncel not ortalaması arasında (r: 0,015; p: 0,957) anlamlı bir ilişki bulunamamıştır. Ancak üniversiteye giriş sınavı puanlarının oransal olarak yüksek olması temel matematiksel işlem yeterliklerinin de oransal olarak anlamlı düzeyde yüksek olmasını sağlamaktadır. Diğer yandan, güncel not ortalaması ile öğrenim yılı arasında pozitif yönde anlamlı bir ilişki belirlenmiştir (r: 0,415; r: 0,001). Buradan, öğretmen adaylarının öğrenimleri sırasında temel matematiksel işlem yeterlikleri arttığında güncel not ortalamalarının da arttığı düşünülebilir.

\section{Görüşmeler}

Ölçekten en yüksek puan alan ve görüşme için seçilen öğretmen adayı erkektir ve eğitiminin 8 . yılındadır. 20 sorudan 18'ini doğru olarak yanıtlamıştır. Yanlış yanıtladığ 1 sorular ise 18. ve 19. sorulardır. Bu sorular, temel trigonometrik İşlemler ulamında yer almaktadır.

Öğretmen adayı, görüşme sırasında yanlış yapmış olduğu soruların doğru yanıtlarını gördüğünde, "Açının yönünü hesaba katmamışım." tepkisini vermiştir. Temel trigonometrik çember üzerinde açının pozitif veya negatif yönlü olabileceği gerçeğini ihmal ettiğini düşünmektedir. Her iki soru için de aynı hatayı yapmışırı.

Ölçekten alınan puanlarda ortancada yer alan ve görüşme yapılan öğretmen adayı kadındır ve eğitiminin 3. yılındadır. Ölçekteki 10 soruya doğru yanıt vermiş, 10 soruya da yanlış yanıt vermiştir. Boş bıraktığı soru yoktur. İlk ulamdaki tüm sorulara doğru yanıt vermiştir. Yanlış yanıt verdiği sorular 
ise, ikinci ulamda yer alan 5. ve 8. sorular, üçüncü ulamda yer alan 9, 11 ve 12. sorular, dördüncü ulamda yer alan 14,15 ve 16 . sorular ve son ulamdaki 17 . ve 18 . sorulardır.

Öğretmen adayının Köklü İfadelerde Temel İşlemler ulamındaki sorularda sayıyı kökten çıkarmada sorun yaşadığı görülmüştür. Örneğin 32 sayısını karekökten çıkarırken 16x2 olduğunu ve 16'nın da karekökten 4 olarak çıkacağını belirleyemediğini ifade etmiştir. Üslü İfadelerde Temel İşlemler ulamında yer alan yanlış yanıtladığı sorular ise üslü ifadelerde toplama ve çıkarma ve üs değiştirme işlemlerini içermektedir. Yapılan görüş̧mede, çarpım durumunda olan iki sayının üslerinde değiştirme yaparken hata yaptığı görülmüştür. Bu nedenle sonuçları hatalı çıkmıştır. Temel Trigonometrik İşlemler ulamındaki sorularda ise açıların yönü ile ilgili yapılan hatalar mevcuttur. Temel trigonometrik çember üzerinde açının pozitif veya negatif yönlü olabileceği gerçeğini ihmal ettiğini ifade etmiştir.

Ölçekten alınan puanlarda en düşük puan alan ve görüşme yapılan öğretmen adayı erkektir ve eğitiminin 3. yılındadır. Ölçekteki sorulardan yalnızca ikisine doğru yanıt vermiş, altısını yanlış yanıtlamış ve geriye kalan 12 soruyu ise boş bırakmıştır. Doğru yanıtladığı sorular 4. ve 10. sorulardır. Yanlış yanıtladığı sorular ise şunlardır: 1, 2, 3, 9, 11 ve 12. sorular. Yanlış yanıtladığı soruların ilk üçü Temel İşlem Bilgisi ulamındadır. Diğer üçü ise Üslü İfadelerde Temel İşlemler ulamındadır.

Öğretmen adayı, Temel İşlem Bilgisi ile ilgili sorularda işlem önceliğini doğru belirleyememiştir. Yapılan görüşmede, işlem önceliğini doğru uygulayamadığı, çoğu zaman ihmal ettiği belirlenmiştir. Üslü İfadelerde Temel İşlemler ulamında yer alan yanlış yanıtladığı sorular ise üslü ifadelerde toplama ve çıkarma ve üs değiştirme işlemlerini içermektedir. Yapılan görüşmede, öğretmen adayının üs değiştirmede başarısız olduğu için bu işlemleri yanlış yaptığı görülmüştür. Çarpım durumunda olan iki sayının üslerinde değiştirme yaparken her ikisinin de üsünü artırdığı veya düşürdüğü görülmüştür. $\mathrm{Bu}$ da sonuçların hatalı çıkmasına neden olmuştur.

Genel olarak görüşmelerden elde edilen veriler, öğrencilerin bazı işlem hataları yaptığı, işlem önceliği, açının pozitif veya negatif oluşunu ihmal etme, üs değiştirme sorunları gibi nedenlerden ötürü sorulara yanlış yanıt verdikleri belirlenmiştir.

\section{TARTIŞMA ve SONUÇ}

Fizik öğretmen adaylarının temel matematiksel işlem becerileri konusundaki yeterlikler incelendiğinde, temel dört işlem ve bir bilinmeyenli birinci dereceden denklem çözme becerilerinin oldukça yüksek düzeyde çıktığı görülmüştür. Ancak öğretmen adaylarının gerek köklü ifadelerde çarpma ve bölme gerekse köklü ifadelerde bir bilinmeyenli birinci dereceden denklem çözme becerisi yetersizdir. Diğer yandan üslü ifadelerde çarpma işlemi konusunda oldukça yeterli iken, üs değiştirme, üslü ifadelerde toplama ve çıkarma, özellikle de üslü ifadelerin kuvvetini alma konusunda ciddi sorunlar yaşamaktadırlar. Öğretmen adayları, logaritmik ifadelerin temel özellikleri ile ilgili işlemler ve temel trigonometrik işlemler konusunda da oldukça yetersizdir. Bu durumda, fizik öğretmeni adaylarının yaşları ve eğitim düzeyleri düşünüldüğünde temel matematiksel işlem becerilerinin dört işlem becerisinin çok ötesine geçemediği söylenebilir. Bu durum düşündürücüdür.

Alanyazın incelendiğinde, bu çalışmanın sonuçları ile uyumlu olarak, öğretmen adaylarının matematiksel okuryazarlık ve matematiksel işlem becerisi gibi konularda yetersiz olduklarına ilişkin çalışmalara rastlanmaktadır. Ancak bu çalışmaların önemli bir bölümü matematik öğretmeni adayları ile gerçekleştirilmiştir. Örneğin, ilköğretim matematik öğretmeni adayları ile yapılan bir çalışmada, ögretmen adaylarının özellikle problemi anlama aşamasında probleme uygun temsil oluşturamama ve temsiller arasında geçiş yapamama gibi sorunlar yaşadıkları tespit edilmiştir (İpek ve Okumuş, 2012). Graeber (1999) öğretmen adaylarının, bu becerilerinin sonraki yıllarda, öğrencilerin yanıtlarını çözümlemede çoklu bir bakış açısı getirebilme konusunda önemli olduğunu söylemektedir. Benzer biçimde, Özgen (2013) tarafından yapılan bir araştırmada, matematik öğretmen adaylarının matematiksel ilişkilendirme becerileri ve problem çözme becerileri ölçülmüştür ve öğretmen adaylarının ilişkilendirme becerilerinin düşük düzeyde olduğu belirlenmiştir.

Öğretmen adaylarının işlemsel bilgiye daha çok önem verdikleri ve işlemsel bilgi ile kavramsal bilgi arasındaki geçişlerde sorunların olduğu bazı çalışmalarda belirlenmiştir (Delice ve Sevimli, 2009; 
Toluk-Uçar, 2011). Benzer bir çalışmada Eli (2009), matematik öğretmen adaylarının bilgilerinin düşük düzeyde olduğunu ve yapılan matematiksel ilişkilendirmenin kavramsal olmaktan çok işlemsel düzeyde olduğunu belirlemiştir. Bu durum, kavramsal ve işlemsel bilgi arasındaki ilişsi göz önüne alındığında çarpıcıdır. Öğretmen adaylarının kavramsal bilgi eksikliklerinin en temel düzeyde bile işlemsel bilgilerini etkilediği düşünülebilir. Nitekim, kavramsal bilginin kazanılması büyük ölçüde işlemsel bilginin kazanılmasını sağlamaktadır (Baki ve Kartal 2004; Hiebert ve Waerne, 1996; Perry, 1991; Rittle-Johnson ve Alibali, 1999). Diğer yandan Dede ve Yaman (2005) tarafından 53 matematik ögretmen adayına problem çözme ve problem kurma becerileri incelenmiştir. Araştırma sonuçlarında ögretmen adaylarının, problemleri çözme konusunda başarılı fakat problem kurma konusunda başarısız oldukları görülmüştür.

Bütüner ve Uzun (2011) ise ilköğretim Fen ve Teknoloji dersindeki öğrencilerin matematiksel bilgilerinin fen konularının öğretimine yönelik etkilerini Fen ve Teknoloji dersi öğretmenlerinin deneyimleri doğrultusunda ortaya koymak amacıyla bir çalışma yapmıştır. Öğretmenler, matematiksel sorunların fen derslerindeki başarıyı doğrudan etkilediği konusunda hemfikirdirler. Temel matematiksel becerilerin fen derslerindeki başarıyı etkilediğine ilişkin çok sayıda çalışma vardır (Boom, Hoijtink ve Kunnen, 2001; Demirci ve Uyanık, 2009; Dole ve Shield, 2008; Roth ve Bowen, 1999). Hatta birim dönüşümlerinde (Kocaoğlu ve Yenilmez, 2010) sorunlar yaşadıkları alanyazında da belirtilmektedir.

Yapılan analizler sonucunda, araştırma bulgularının cinsiyetten bağımsız olduğu görülmüştür. Ancak öğretmen adaylarının temel dört işlem becerisi ile öğrenim yılları arasında negatif yönde bir ilişki belirlenmiştir.

Öğretmen adaylarının gerek güncel not ortalamaları gerekse üniversiteye giriş puanları ile matematiksel işlem becerileri arasında da kısmen pozitif ilişki bulunmuştur. Bu durum, öğretmenlik alanlarına daha yüksek puanla öğrenci alınmasının gerekliliğini göstermesi bakımında çarpıcıdır. Ayrıca öğretmen adaylarının işlem becerilerindeki yeterliğinin veya yetersizliğinin güncel not ortalamalarını etkilediği düşünülebilir. Yani işlem bilgisi, güncel not ortalamasını doğrudan etkilemektedir denebilir.

Gelecekteki fizik öğretmenleri olan fizik öğretmeni adaylarının matematiksel işlem becerilerinin yüksek olması beklenmelidir. Çünkü fen bilimlerinin bir dalı olan fizik ile matematik arasındaki ilişki göz önüne alınırsa, alan bilgisi açısından yeterli olabilmeleri, matematiksel işlem yeterlikleri ile ilişkili olacaktır. Diğer fen bilimleri alanlarında öğrenim gören öğrencilerin de matematiksel işlem yeterlilikleri ile ilişkisi incelenmelidir. Bu durumda, başta fizik öğretmenliği gibi matematiksel işlem yeterliliği ile yakından ilişkisi bulunabilecek diğer fen bilimleri alanları olmak üzere öğretmenlik alanlarına üniversiteye giriş sisteminde daha yüksek puanlarla öğrenci alınması önemlidir. Ayrıca matematik eğitimine önem verilmesi ve işlem becerilerinin artırılması için yeni araştırmalar yapılması gereklidir. Ayrıca fen bilimleri alanlarında öğrenim gören öğretmen adaylarının çeşitli konulardaki başarısızlık nedenleri incelenirken, matematiksel becerileri de dikkate alınmalıdır.

\section{KAYNAKÇA}

Aksu, M. (1985). Ortaögretim kurumlarında matematik ögretimi ve sorunları. Ankara: TED Yayınları.

Akyüz, G. ve Pala, N. M. (2010). PISA 2003 sonuçlarına göre öğrenci ve sınıf özelliklerinin matematik okuryazarlığına ve problem çözme becerilerine etkisi. Illköğretim Online, 9(2), 668-678.

Albayrak, M., İpek, A. S. ve Işık, C. (2006). Temel işlem becerilerinin öğretiminde problem kurma çözme çalışmaları. Erzincan Eğitim Fakültesi Dergisi, 8(2), 1-11.

Baki, A. (1997). Educating mathematics teachers. Medical Journal of Islamic Academy of Sciences, 10(3), 93-102.

Baki, A. (1998). Matematik ögretiminde işlemsel ve kavramsal bilginin dengelenmesi. Atatürk Üniversitesi 40. Kuruluş Yıldönümü Matematik Sempozyumu, Atatürk Üniversitesi, Erzurum. 
Baki, A., Kartal, T. (2004). Kavramsal ve işlemsel bilgi bağlamında lise öğrencilerinin cebir bilgilerinin karekterizasyonu. Türk Ë̆itim Bilimleri Dergisi, 2(1), 27-46.

Baykul, Y. (2005). Illköğretimde matematik öğretimi. Ankara: Pegem A Yayıncılık.

Bekdemir, M., ve Duran, M. (2012). İlköğretim öğrencileri için görsel matematik okuryazarlı̆̆1 özyeterlik alg1 ölçeğinin geliştirilmesi. Ondokuz Mayıs Üniversitesi Eğitim Fakültesi Dergisi, 31(1), 89-115.

Bekdemir, M., Okur, M. ve Gelen, S. (2010). 2005 İlköğretim matematik programının ilköğretim yedinci sınıf öğrencilerinin kavramsal, işlemsel bilgi ve becerilerine etkisi. Erzincan Eğitim Fakültesi Dergisi, 12(2), 131-147.

Bodner, B.L., (2006). Bridges 2006: Mathematical connectins in art, music, and science. Conference Report. 4-9 August 2006, London. Nexus Network Journal, 9(1), 145-149.

Boom, J., Hoijtink, H. ve Kunnen, S. (2001). Rules in the balance: Classes, strategies, or rules for the balance scale task? Cognitive Development, 16, 717-735.

Brown, M. (2002). The effectiveness of the national numeracy strategy: Evidence from the Leverhulme Research Programme and other studies at King's College. London: King's College.

Bülbül, S. Kavak, Y. Gülbay, Ö. (1999). Yetişkinlere yönelik okuma-yazma kurslarının değerlendirilmesi araştırması. Nihai Rapor. Ankara: MEB/UNICEF Türkiye Temsilciliği.

Bütüner, S. Ö. ve Uzun, S. (2011). Fen öğretiminde karşılaşılan matematik temelli sıkıntılar: Fen ve teknoloji öğretmenlerinin tecrübelerinden yansımalar. Kuramsal Eğitimbilim, 4(2), 262-272.

Çetinkaya, A. ve Soybaş, D. (2018). İlköğretim 8. sınıf öğrencilerinin problem kurma becerilerinin incelenmesi. Kuramsal Eğitimbilim Dergisi, 11(1), 169-200.

Dede, Y. ve Yaman, S. (2005). Matematik öğretmen adaylarının matematiksel problem kurma ve problem çözme becerilerinin belirlenmesi. Eğitim Araştırmaları Dergisi, 18, 236-252.

Delice, A. ve Sevimli, E., (2010). Matematik öğretmeni adaylarının belirli integral konusunda kullanılan temsiller ile işlemsel ve kavramsal bilgi düzeyleri. Gaziantep Üniversitesi Sosyal Bilimler Dergisi, 9(3), 581-605.

Demir, G. ve Akar Vural, R. (2017). Ortaöğretim matematik programının hedeflediği matematiksel yeterlilik ve becerilerinin kazandırılma sürecinin öğretmen görüşleri temelinde incelenmesi. Adnan Menderes Üniversitesi Sosyal Bilimler Enstitüsü Dergisi, 4(1), 118-139.

Demirci, N., Uyanık, F. (2009). Onuncu sinıf öğrencilerinin grafik anlama ve yorumlamaları ile kinematik başarıları arasındaki ilişki. Necatibey Eğitim Fakültesi Elektronik Fen ve Matematik Eğitimi Dergisi (EFMED), 3(2), 22-51.

Dole, S., Shield, M. (2008). the capacity of two australian eighth-grade textbooks for promoting, Proportional Reasoning, Research in Mathematics Education, 10(1), 19-35.

Dursun, Ş. ve Dede, Y. (2004). Öğrencilerin matematikte başarısını etkileyen faktörler: Matematik öğretmenlerinin görüşleri bakımından. GÜ Gazi Eğitim Fakültesi Dergisi, 24(2), 217-230.

Eli, J.A., (2009). An exploratory mixed methods study of prospective middle grades teachers' mathematical connections while completing investiagtive tasks in geometry. Unpublished $\mathrm{PhD}$ Disseration, University of Kentucky, USA.

Eli, J.A., Mohr-Schroeder, M.J., and Lee, C.W., (2011). Exploring mathematical connections of prospective middle-grades teachers through card-sorting tasks. Mathematics Education Research Journal, 23(3), 297-319.

Evitts, T.A., (2004). Investigating the mathematical connections that preservice teachers use and develop while solving problems from reform curricula. Unpublished $\mathrm{PhD}$ Disseration, Pennsylvania State University College of Education, USA. 
Flores, A., (1992). Mathematical connection with a spirograph. The Mathematics Teacher, 85(2), 129132.

Furner, M. J., Kumar, D. D. (2007). The mathematics and science integration argument: A stand for teacher education. Eurasia Journal of Mathematics, Science ve Technology Education, 3(3), 185189.

Graeber, A. (1999). Forms of knowing mathematics: What preservice teachers should learn. Educational Studies in Mathematics, 38, 189-208.

Güleç, S. ve Alkış, S.(2003). İlköğretim birinci kademe öğrencilerinin derslerdeki başarı düzeylerinin birbiriyle ilişkisi. Ilkögretim Online, 2(2), 19-27.

Güneş, F. (1990). Okumaz-Yazmaz yetişkinler araştırması. Ankara Üniversitesi Eğitim Bilimleri Fakültesi. Yayımlanmamış araştırma raporu. Ankara.

Güneş, G. ve Gökçek, T. (2013). Öğretmen adaylarının matematik okuryazarlık düzeylerinin belirlenmesi. Dicle Üniversitesi Ziya Gökalp Eğitim Fakültesi Dergisi, 20, 70-79.

Günlü, S. (2005). Dönemsel değişimler ışı̆̆ı̆nda Türkiye'de okuma-yazma kampanyalarının değerlendirilmesi. Yayımlanmamış doktora tezi. Ankara Üniveritesi Eğitim Bilimleri Enstitüsü. Ankara.

Hiebert, J., Waerne, D. (1996). Instruction, understanding and skill in multidigit addition and instruction. Cognition and Instruction, 14, 251-283.

İpek, A. S. ve Okumuş, S. (2012). İlköğretim matematik öğretmen adaylarının matematiksel problem çözmede kullandıkları temsiller. Gaziantep Üniversitesi Sosyal Bilimler Dergisi, 11(3), 681-700.

Jarvis, P.(2005). An international dictionary of adult and continuing education. London: Routludge.

Kaya, D. ve Keşan, C. (2014). İlköğretim seviyesindeki öğrenciler için cebirsel düşünme ve cebirsel muhakeme becerisinin önemi. Journal of New Trends in Arts, Sports ve Science Education, 3(2), $38-48$.

Kocaoğlu,T., Yenilmez, K. (2010). Beşinci sınıf öğrencilerinin kesir problemlerinde yaptıkları hatalar ve kavram yanılgıları. Dicle Üniversitesi Ziya Gökalp Eğitim Fakültesi Dergisi, 14, 71-85.

Korkmaz, E. ve Gür, H. (2006). Öğretmen adaylarının problem kurma becerilerinin belirlenmesi. BAÜ Fen Bilimleri Enstitüsü Dergisi, 8(1), 64-74

Lincoln, Y. S. ve Guba, E. G. (1985). Naturalistic inquiry. Beverly Hills, CA: Sage.

MEB (2008). PISA'da okuma becerileri: PISA'da matematik okuryazarlı̆̆. 10 Ağustos 2013 tarihinde $<$ http://earged.meb.gov.tr> adresinden erişildi.

MEB (2017). Öğretmenlik mesleği genel yeterlikleri. Öğretmen Yetiştirme ve Geliştirme Genel Müdürlüğü, Ankara. 10 Aralık 2017 tarihinde http://oygm.meb.gov.tr/www/ogretmenlik-meslegigenel-yeterlikleri/icerik/39 adresinden erişildi.

Monroe, E.E. and Mikovch, A.K., (1994). Making mathematical connection across the curriculum: Activities to help teachers begin. School Science and Mathematics, 94(7), 371-376.

Nohl, A.-M. ve Sayılan, F. (2004). Türkiye'de yetişkinler için okuma-yazma eğitimi. Temel Eğitime Destek Projesi Teknik Raporu. Ankara: Milli Eğitim Bakanlı̆̆ı/Avrupa Komisyonu.

Olkun, S., Toluk Z.,(2004). İlkögrretimde etkinlik temelli matematik öğretimi.Ankara: AnıYayıncılık.

Orton, T., Roper, T. (2000). Science and mathematics: A relationship in need of counselling? Studies in Science Education, 35, 123-154.

Özgen, K. (2013). Problem çözme bağlamında matematiksel ilişkilendirme becerisi: Öğretmen adayları örneği, NWSA-Education Sciences, 1C0590, 8(3), 323-345. 
Özgen, K. ve Bindak, R. (2011). Lise öğrencilerinin matematik okuryazarlı̆̆ına yönelik öz-yeterlik inançlarının belirlenmesi, Kuram ve Uygulamada Ĕ̆itim Bilimleri, 11(2), 1073-1089.

Perry, M. (1991). Learning and transfer: Instructional conditions and conceptual change. Cognitive Development, 6, 449-468.

Rittle-Johson, B., Alibali, M. W. (1999). Conceptual and procedural knowledge of mathematics: Does one lead to the other? Journal of Educational Psychology, 99, 175-189.

Roth, W, M. ve Bowen, G.M. (1999). Complexities of graphical representations during ecology lectures: an analysis rooted in semiotics and hermeneutic phenomenology. Learning and Instruction, 9, $235-255$.

Schwalbach, E.M., and Dosemagen, D.M., (2000). Developing student understanding: Contextualizing calculus concepts. School Science and Mathematics, 100(2), 90-98.

Tanışlı, D. (2013). İlköğretim matematik öğretmeni adaylarının pedagojik alan bilgisi bağlamında sorgulama becerileri ve öğrenci bilgileri. Eğitim ve Bilim, 38(169), 80-95.

Tekin, B. ve Tekin, S. (2004). Matematik öğretmen adaylarının matematiksel okuryazarlık düzeyleri üzerine bir araştırma. 27 Mart 2018 tarihinde http://www.matder.org.tr/ adresinden erişildi.

Toluk-Uçar, Z., (2011). Öğretmen adaylarının pedagojik içerik bilgisi: Öğretimsel açıklamalar. Turkish Journal of Computer and Mathematics Education, 2(2), 87-102.

Tutak, T, Gün, Z. ve Emül, N. (2010). Matematik eğitiminde ilköğretim düzeyinde kavramla ilgili yapılan çalışmaların bir değerlendirmesi. 9. Ulusal Sınıf Öğretmenliği Eğitimi Sempozyumu, Elazı̆g, 235-240.

Tüzel, M.S. (2010). Görsel okuryazarlık. Türklük Bilimi Araştırmaları, 27, 691-705.

Umay, A., (2007). Eski arkadaşımız okul matematiğinin yeni yüzü. Ankara: Aydan Web Tesisleri.

Uysal, E. ve Yenilmez, K. (2011). Sekizinci sınıf öğrencilerinin matematik okuryazarlığı düzeyi. Eskişehir Osmangazi Üniversitesi Sosyal Bilimler Dergisi, 12(2), 1-15.

Uzun, S., Bütüner, S. Ö. ve Yiğit, N. (2010). 1999-2007 TIMSS Fen bilimleri ve matematik sonuçlarının karşılaştırılması: Sınavda en başarılı ilk beş ülke-Türkiye örneği. İlköğretim Online, 9(3), 11741188

Wang, J. (2005). Relationship between mathematics and science achievement at the 8th grade. International Online Journal of Science Mathematics Education, 5, 1-17.

Yenilmez, K. (2007). İlköğretim matematik öğretiminde karşılaşılan zorluklar ve nedenleri. XVI. Ulusal Eğitim Bilimleri Kongresi, Gaziosmanpaşa Üniversitesi Eğitim Fakültesi, Tokat.

Yıldız, A. (2006). Türkiye'de yetişkin okuryazarlığı: Yetişkin okuma-yazma eğitimine eleştirel bir yaklaşım. Yayımlanmamış doktora tezi, Ankara Üniversitesi, Eğitim Bilimleri Enstitüsü, Ankara.

Yıldız, A. (2010). Birinci kademe okuma-yazma kurslarına katılan yetişkinlerin matematik becerileri üzerine bir araştırma. Eğitim ve Bilim, 35(158), 28-43. 